\title{
TEKS MANTRA EMBEUNG BEURANG SEPUTAR KEHAMILAN DAN KELAHIRAN BAYI DI CIDOLOG KABUPATEN SUKABUMI
}

\author{
David SetiadidanAsep Firdaus \\ Universitas Muhammadiyah Sukabumi \\ (idaites10@yahoo.com)
}

\begin{abstract}
ABSTRAK
Mantra sebagai salah satu genre sastra lisan, pada masanya dijadikan masyarakat Nusantara sebagai jawaban dalam menangani permasalahan-permasalahan kehidupan. Pada masanya akibat kurangnya ilmu pengetahuan medis modern dalam menangani permasalahan seputar kehamilan dan kelahiran bayi menjadikan mantra sebagai salah satu solusi penyelesaiannya. Tujuan penelitian ini adalah memaparkan struktur teks mantra seputar masa kehamilan, dan kelahiran bayi, ditinjau dari sisi makna dan fungsi. Metode yang digunakan dalam penelitian ini menggunakan metode penelitian kualitatif dengan cara deskriptif analisis. Teknik pengumpulan data dilakukan melalui proses wawancara, perekaman, dan pencatatan. Wawancara bebas digunakan dengan harapan informan dapat memberikan informasi secara terbuka. Perekaman dan pencatatan dilakukan dalam upaya mengalihbahasakan teks mantra dari lisan menjadi bentuk tulisan. Sehingga melalui proses alih bahasa tersebut, teks mantra-mantra yang ada seputar masa kehamilan dan kelahiran dapat diarsipkan sebagai warisan budaya nusantara.
\end{abstract}

Kata kunci:sastra lisan, mantra, folklor

\section{A. PENDAHULUAN}

Kehidupan sastra lisan bagi masyarakat Cidolog pada masanya merupakan satu bagian yang sangat penting, karena banyak sangkut pautnya dengan tradisi peradatan. Dalam perkembangannya, kehidupan sastra secara keseluruhan tidak dapat dilepaskan dari sastra tradisional setiap daerah. Effendi dan Sabhan (2007: 87) menyatakan bahwa sastra daerah merupakan peninggalan budaya masyarakat bangsa kita yang tidak ternilai harganya. Fungsinya sebagai penunjang perkembangan bahasa daerah dan sebagai pengungkap alam pikiran, sikap, dan nilai-nilai kebudayaan masyarakat pendukungnya. Di dalam sastra daerah itu, terpendam berbagai nilai yang dianut oleh nenek moyang kita pada masa lalu. Dari sekian banyak sastra lisan masyarakat Cidolog tersebut, yang menjadi objek penelitian ini adalah mantra.

Sastra dapat dikelompokkan ke dalam dua golongan besar, yakni sastra tradisional dan sastra kontemporer. Sastra tradisional adalah karya sastra yang 
ada dan memulai perkembangannya pada minimal dua generasi yang lalu. Sastra kontemporer adalah karya sastra yang dikenal atau telah ada setelah sastra tradisional. Robson (dalam Ismail, 1996:1) menyatakan tidak ada sastra tradisional dalam bahasa Indonesia, yang ada hanya bahasa Melayu dan bahasa daerah lainnya, maka dalam masyarakat Cidolog, kini masih dikenal keberadaan sastra lisan. Wujud bahasa yang paling natural adalah bahasa lisan (Effendi, 2011:2). Sastra (lisan dan tulisan) adalah satu bentuk kesenian yang diwujudkan melalui bahasa yang diucapkan. Sastra lisan, di samping sebagai karya sastra, juga dapat dipandang sebagai folklor.

Folklor adalah sebagian kebudayaan suatu kolektif, yang tersebar dan diwariskan turun temurun, dan menggunakan alat bantu, seperti gendang dan bunyi-bunyi lain, atau juga dibantu dengan gerakan anggota badan, seperti mimik, tari-tarian, mamang (gumam), juga benda-benda yang dianggap dapat memperkuat kekuatan tuturan dan mamang. Menurut Danandjaja (dalamSudikan, 2001:98), folklor adalah sebagian kebudayaan yang tersebar dan diwariskan secara turun temurun secara tradisional, baik dalam bentuk lisan atau disertai dengan gerak isyarat atau alat pengingat. Sastra lisan masyarakat Cidolog Jampang kabupaten Sukabumi diucapkan dalam bahasa daerah itu sendiri, karena kebudayaan dalam bidang sastra ini adalah berbentuk lisan dalam pengucapannya, maka dipandang memiliki keunikan tersendiri dan berbeda dari mantra yang dimiliki oleh etnik lainnya biasanya diikuti dengan gendang dan bunyi-bunyi lain, atau juga dibantu dengan gerakan anggota badan, seperti mimik, tari-tarian beserta dengan gelang tangan dan kaki yang digunakan, mamang (gumam), juga benda-benda yang dianggap dapat memperkuat kekuatan tuturan danmamang. Sastra lisan ini mencakup ekspresi sastra warga suatu kebudayaan yang disebarluaskan dan diwariskan turun-temurun secara lisan (dari mulut ke mulut).

Membaca mantra adalah upaya untuk memohon perlindungan kepada Tuhan, baik secara langsung maupun dengan melalui perantaraan makhluk gaib. Pembacaan mantra di Cidolog ini, biasanya dipimpin oleh seorang yang dianggap sakti atau orang pintar yang dapat menghubungkan dunia alam gaib dengan manusia. Salah satu orang yang dianggap sakti itu adalah seorang dukun beranak 
(mbeung beurang). Bagi masyarakat Cidolog Mbeung Beurangdianggap mempunyai kesaktian dengan mantranya untuk mengurus persalinan ibu hamil dan kelahiran bayi.

Mbeung beurang dianggap oleh masyarakat Cidolog sebagaiseorang pemantra yang dianggap sakti atau orang pintar yang dapat menghubungkan dunia alam gaib dengan manusia.

Sastra daerah merupakan sastra yang dihasilkan masyarakat yang masih dalam keadaan tradisional masyarakatnya dan tertuang dalam bahasa daerah masyarakat itu sendiri. Masyarakat Cidolog memiliki tradisi lisan yang diturunkan dari generasi ke generasi dengan cara menghafal. Mantra adalah ucapan yang dianggap mengandung hikmah dan kekuatan gaib. Karena itu, harus tersimpan rapi di benak atau ditulis dalam buku yang suci penggunanya. Sebagai bentuk tradisi lisan seperti ini, sukar dipastikan penciptanya. Masyarakat Cidolog bahkan sampai saat ini masih ada yang menganut kepercayaan pada kekuatan gaib, misalnya pada mantra karena masyarakat berada pada pihak yang membutuhkan pertolongan, mereka berupaya kepada yang dapat memberi pertolongan. Oleh karena referensi mantra menunjuk pada sistem kepercayaan, religi dan dunia gaib maka eksistensinya mantra hanya dapat dipahami secara lengkap dengan mengembalikan pada kenyataan, emosi, dan asosiasi yang tumbuh dari penghayatan dan pengalaman dunia spiritual dan magis.

Seseorang yang ingin menguasai mantra harus belajar dan meyakini sungguh-sungguh hikmat dan kekuatan gaib yang tersimpan di dalam susunan kata-kata yang diucapkan. Mantra yang diucapkan dalam bahasa Sunda dan terkadang diawali, disisipi, dan diakhiri dengan bahasa Arab ini lebih menunjukkan pada sifat latennya, yang memerlukan satu upaya serius untuk mengungkapkan fungsi apa dan latar belakang kepercayaan yang bagaimana yang mendasarinya. Karena cara penyebaran mantra ini biasanya adanya keturunan, perguruan, dan penjelmaan melalui mimpi.

Berdasarkan latar belakang yang dikemukakan di atas, penelitian ini berupaya untuk menjawab masalah yang berkaitan dengan struktur, makna, dan fungsi teks mantra Mbeung Beurang di Cidolog.Manfaat yang dituju dalam penelitian ini meliputi manfaat secara teoretis dan praktis. Secara teoretis, 
manfaat penelitian berguna bagi perkembangan penelitian sastra lisan. Terutama dalam menambah khazanah referensi penelitian folklor, yang secara khusus meneliti permainan anak tradisional. Secara praktis, penelitiaan ini dapat menjadi salah satu cara dalam melestarikan khazanah budaya lokal.

\section{Metode Penelitian dan Landasan Teoretis}

Metode yang digunakan dalam penelitian ini menggunakan metode penelitian kualitatif dengan cara deskriptif analisis. Adapun metode yang dipergunakan bertujuan untuk mengumpulkan, mengklarifikasi, dan menganalisis data sehingga diperoleh gambaran yang menyeluruh mengenai struktur ditinjau dari segi makna dan fungsi mantra pada masyarakat Cidolog Jampang Kabupaten Sukabumi.Teknik pengumpulan data dalam penelitian ini untuk dapat menggambarkan secara objektif makna dan fungsi mantra bagi masyarakat Cidolog. Peneliti melakukan penelitian dengan tahapan-tahapan sebagai berikut:

1. observasi langsung untuk mengetahui lingkungan penutur mantra,

2. teknik simak libat cakap,

3. menerjemahkan, mengklafikasikan, mendata penutur, menguraikan fungsi serta pelaksanaan mantra dalam masyarakat Cidolog,

4. studi pustakaadalah mencari dan mengumpulkan bahan-bahan referensi yang digunakan sebagai landasan teoretis dalam penelitian ini.

\section{Sastra Lisan}

Budaya lisan secara etimologi berasal dari "Oral Cultur". Pembicaraan budaya lisan dipertentangan dengan sastra lisan atau cerita rakyat yang pada umumnya berbentuk lisan. Muncul istilah sastra lisan yang merupakan terjemahan istilah bahasa asing yaitu oral literatur. Sastra lisan adalah kesusastraan yang mencakup ekspresi sastra warga suatu kebudayaan dan diturun-temurunkan secara lisan dari mulut ke mulut (Danandjaja, 1997:19). Selanjutnya Atmazaki (1993:82) berpendapat bahwa sastra lisan adalah sastra yang disampaikan secara lisan dari mulut ke mulut oleh seorang pencerita atau penyair kepada pembaca atau kelompok pendengar. Senada dengan hal tersebut Arifin mengemukakan bahwa sastra lisan merupakan sastra lama yang disampaikan secara lisan (dari mulut ke 
mulut) umumnya disampaikan baik dengan musik atau tidak (1990:3). Sastra lisan merupakan suatu unsur kebudayaan yang sangat menonjol dalam daerah tertentu (Soedjijono dkk, 1990:3). Hutomo (dalam Srizul, 2001:9) membagi sastra dalam tiga bagian yaitu sebagai berikut:

1) bahasa yang bercorak cerita seperti cerita bahasa dan legenda,

2) bahasa yang bukan cerita ungkapan, nyanyian, peribahasa, teka-teki, puisi lisan, dan nyanyian sedih,

3) dan bahasa yang bercorak latihan seperti latihan drama dan pentas.

Dalam hubungan dengan hal itu, Danandjaja (2002:22) membagi sastra lisan dalam enam jenis yaitu: (1) bahasa rakyat seperti sindiran dan mantra, (2) ungkapan tradisional seperti pepatah, peribahasa, dan seloka, (3) pertanyaan tradisional seperti teka-teki, (4) cerita rakyat seperti mitos, legenda, dan dongeng, (5) puisi rakyat seperti pantun, syair, bidal, dan gurindam, (6) nyanyian rakyat.

\section{Mantra}

Mantra adalah dua istilah yang telah resmi pemakaiannya dalam bahasa Indonesia. Dilihat dari segi maksud dan tujuannya, mantra belum mempunyai perbedaan yang jelas dengan doa. Oleh karena itu, orang kadang-kadang menyamakan doa dengan mantra. Dalam konteks penelitian ini, perbedaan yang mendasar antara mantra dan doa adalah pemakaian istilah saja. Sedangkan perbedaan mendasar lainnya tampak dalam pemakaian bahasanya. Apabila ditinjau dari segi tinjauan mantra dan doa mempunyai kesamaan, yaitu sama-sama mengundang arti permohonan terhadap kekuatan yang gaib untuk memenuhi harapan atau keinginan. Namun demikian kedua kata tersebut belum digolongkan sebagai kata yang bersinonim.

Kekaburan perbedaan makana antara mantra dengan doa tidak menghalangi orang mengidentifikasikan mantra maupun doa secara terpisah seperti berikut ini.

Mantra adalah kata-kata yang mengandung khidmat kekuatan gaib, biasanya diucapkan oleh pawang. Kesalahan dalam mengucapkan mantra dianggap dapat mendatangkan marah bahaya. Sedangkan Badudu (1984 : 5-6) memberi batasan tentang mantra sebagai suatu bentuk puisi lama dan dianggap 
sebagai puisi tertua di Indonesia. Kata dan kalimatnya tetap merupakan aturan yang tidak bisa ditawar lagi. Kedua pendapat yang dikemukakan tadi, terangkum dalam Kamus Umum Bahasa Indonesiayang mengartikan mantra sebagai: (a) perkataan atau ucapan yang dapat mendatangkan daya gaib, (b) susunan kata berunsur puisi (rima, irama) yang dianggap mengandung kekuatan gaib yang lain (Debdikbud, 1995 : 558).

Berdasarkan beberapa pengertian yang telah dikemukakan di atas, maka dapat dipahami bahwa mantra itu berupa ucapan atau perkataan yang dapat mendatangkan kekuatan gaib. Namun demikian, di dunia yang serba modern ini tidak semua ucapan-ucapan dalam mantra itu terbukti kekuatannya. Hal tersebut disebabkan oleh kondisi dari manusia itu sendiri serta kemajuan ilmu pengetahuan dan teknologi.

Mantra merupakan bentuk puisi lama yang erat pula dengan kepercayaan sejak masa purba. Kata-kata dalam mantra dianggap mengandung kekuatan gaib. Mantra ditujukan kepada makhluk gaib, maka kalau dihadapkan kepada manusia itu menjadi sesuatu yang tidak mudah dipahami dan bahkan tidak mempunyai arti. Yang dipentingkan dalam sebuah mantra adalah bukannya bagaimana dapat memahaminya, akan tetapi bagaimana dapat memberikan kontribusi bagi kehidupan manusia.

Selanjutnya menurut Djamaris (1996:20) mengatakan bahwa mantra merupakan suatu gubahan bahasa yang diresapi oleh kepercayaan dunia gaib dan sakti. Dalam Kamus Istilah Sastra, Sudjiman (1990:58) mengatakan bahwa mantra dapat mengandung tantangan atau kekuatan terhadap sesuatu kekuatan gaib dan dapat berisi bujukan agar kekuatan gaib tersebut tidak berbuat yang merugikan.

Pada dasarnya mantra adalah ucapan yang tidak perlu dipahami, sehingga ia kadang-kadang tidak dipahami karena ia lebih merupakan permainan bunyi dan bahasa belaka. Sebagai sebuah mantra ia mesti mempunyai sifat-sifat yang ada pada sebuah mantra. Bahasa sebuah mantra bersifat esoterik yang tidak mudah dipahami, bahkan mungkin tidak mempunyai arti nominal.

Mantra adalah unsur irama yang berpola tetap yang perwujudannya dapat berupa pertentangan yang berselang seling antara suku yang panjang dengan suku 
yang tidak beraksen (Kamus Sastra Indonesia, 1991:79). Suatu mantra yang diucapkan dengan tidak semestinya, salah lagunya, dan sebagainya, maka hilang pula kekuatannya. Sebuah mantra pada dasarnya menghubungkan manusia dengan dunia yang penuh dengan misteri atau gaib untuk atau tidak melakukansesuatu terhadap manusia yang mengucapkannya.sebuah mantra dinilai dari kemajutannya bukan dari kejelasan penyampaiannya, yang penting bagi sebuah mantra bukanlah bagaimana orang dapat memahaminya, tapi kenyataannya sebagai sebuah mantra. Kemanjurannya sebagai sebuah mantra juga tidak meminta untuk dipahami, karena tidak ada persoalan pemahaman.

Mantra adalah karya sastra lama dan dianggap sebagai puisi tertua di Indonesia, yang berisikan puji-pujian terhadap sesuatu yang gaib atau pun sesuatu yang dianggap harus dikeramatkan seperti dewa-dewa, roh-roh, binatang-binatang ataupun Tuhan, biasanya diucapkan oleh dukun dan pawang. Mantra adalah puisi magis, yang merupakan alat untuk mencapai tujuan dengan cara yang luar biasa. Apabila dalam hidupnya orang menemui permasalahan yang tidak dapat dipecahkan melalui akal dan pikiran, maka mereka akan mempergunakan mantramantra, dengan mengharapkan tujuan akan tercapai.

\section{Mantra dalam Masyarakat}

Mantra dan masyarakat mempunyai hubungan yang erat. Artinya, mantra tercipta dari masyarakat. Mantra tidak mungkin ada jika tidak ada masyarakat pewarisnya. Demikian pula yang terjadi pada masyarakat tradisional yang berpegang teguh pada adat istiadatnya, tidak dapat dipisahkan dari kehidupan mantra. Kepercayaan akan adanya kekuatan gaib selalu mendorong mereka untuk merealisasikan kekuatan tersebut kedalam wujud nyata untuk memenuhi kebutuhannya.

Namun harus diakui pula bahwa keberadaan mantra dewasa ini berbeda dengan mantra sebelumnya. Hal ini disebabkan terjadinya pegeseran nilai-nilai budaya dalam masyarakat. Mantra adalah sesuatu yang lahir dari masyarakat sebagai perwujudan dari keyakinan atau kepercayaannya. Terutama dalam masyarakat tradisional, mantra bersatu dan terintegrasi dalam kehidupan seharihari. Seorang pawang atau dukun yang ingin menghilangkan wabah penyakit 
dapat dilakukan dengan membacakan mantra-mantranya. Masih banyak lagi kegiatan-kegiatan lain terutama yang berhubungan dengan adat biasanya didahului dengan mantra. Menurut kepercayaan mereka bahwa dengan mengucapkan mantra itu kegiatan mereka akan sukses dan mempunyai berkah. Kebiasaan ini berlangsung secara turun-temurun, dan sampai sekarang masih kita temukan dalam mayarakat terutama dalam masyarakat pedesaan. Oleh karena itu, mantra sebagai karya yang lahir dari masyarakat maka keberadaannya tidak bisa dipisahkan dari kehidupan masyarakat.

\section{B. PEMBAHASAN}

\section{Analisis Struktur Mantra}

Berdasarkan observasi yang telah dilakukan peneliti di desa Cidolog Jampang Kabupaten Sukabumi, peneliti mendapatkan empat mantra yang berhubungan dengan kelahiran bayi. Mantra-mantra tersebut memiliki fungsi dan tujuan masing-masing. Adapun dilihat dari sisi struktur mantra tersebut meliputi unsur judul, unsur pembuka, unsur sugesti, dan unsur tujuan.

\section{a. Unsur Judul}

Judul merupakan unsur pokok yang penting. Dengan adanya judul pada sebuah buku, puisi, cerpen, lagu, koran dan lain-lain, maka dengan mudah mengetahui isi dari tulisan tersebut. Dalam sebuah mantra, unsur judul merupakan salah satu unsur pokok karena dengan adanya judul dalam sebuah mantra dapat mempermudah membedakannya, dan terlihat jelas tujuan, dan fungsi mantra yang bersangkutan.

\section{b. Unsur Pembuka}

Setiap mantra memiliki unsur pembuka, keempat mantra yang dikumpulkan yang dimiliki oleh masyarakat Cidologmempunyai unsur pembuka yang sama. Unsur pembuka adalah kata pertama yang terdapat pada mantra yang berisi salam pembuka. Biasanya menggunakan kata-kata yang diadopsi dari bahasa Arab, bahasa Sanskerta (Hindu), dan bahasa Jawa. Komponen pembuka merupakan pengakuan tunduk dan mohon perlindungan penguasa semesta.

\section{c.Unsur Sugesti}


Unsur sugesti ini adalah unsur yang berisi metafora yang dianggap memiliki kekuatan gaib pada mantra yang diucapkan atau dalam rangka membantu untuk membangkitkan potensi kekuatan magis atau gaib pada mantra. Unsur yang membangun pada mantra-mantra yang dikumpulkan adalah unsur sugesti.

\section{d. Unsur Tujuan}

Tujuan adalah sesuatu yang hendak dicapai oleh seorang dukun atau pemantra dalam menggunakan mantra atau mengamalkan mantra. Unsur tujuan pada mantra merupakan suatu permohonan atau keinginan agar denganmantramantra yang ia ucapkan dapat berfungsi sebagai menyembuhkan penyakit, memanggil hujan, untuk diri sendiri, dan lain-lainnya. Unsur tujuan juga berfungsi untuk membedakan mantra satu dengan mantra yang lain karena tiaptiap mantra memiliki tujuannya masing-masing.

\section{1) Mantra ngereut tali udel}

\section{TRANSKRIPSI}

Bismillahirrahmanirrahim

Tutugulan tetegeulan

Ditegel ku peso pati

Hirup ku gusti

Waras ku Aloh

Waras ku kersaning Aloh

\section{TERJEMAHAN}

Dengan menyebut nama Allah

yang maha pengasih lagi maha

penyayang

tutugulan teteugeulan

dipotong dengan pisau nyawa

hidup oleh Allah

sehat oleh Allah

sehat dengan izin Allah

\section{Tabel 1}

\section{Unsur Struktur}

Unsur Judul

Unsur Pembuka

Unsur Sugesti

Unsur Tujuan

\section{Unsur Isi Struktur}

Ngeureut

Bismillahirrahmanirrahim

Tutugulan teteugeulan ditegeul ku peso pati

Waras ku kersaning Aloh

\section{2) Mantra ngeureut santeun}


TRANSKRIPSI

Bismillahirrahmanirrahim

a) Ceupil ulah sakuping-kupingna lamun lain kupingeun nana

b) lambei ulah sok sacarioscariosna lamun lain cariosennana

c) soca ulah satingali-tingalieunna lamun lain tingalieunnana

d) sampean, ulah sok satincaktincakna lamun lain tincakeunnana

e) panangan ulah sok sacanakcanakna upami sanes canakeunana

\section{3) Mantra ngeusian kanyut kunang} TRANSKRIPSI

Bismillahirrahmanirrahim

Mihapekeun eta ka kaleuweungna

kataina

Kadaratna ka remana

Janari teungah peuting

Beurang kumaha oge

Mihape ka kangjeng nabi

Muhammad

\section{TERJEMAHAN}

Dengan menyebut nama Allah yang maha pengasih lagi maha penyayang
a) Telinga Jangan mendengarkan sesuatu yang tidak pantas didengar

b) Bibir jangan bicara sembarangan

c) Mata tidak boleh melihat sesuatu yang tidak pantas dilihat

d) Kaki jangan suka dilangkahkan untuk jalan yang tidak benar

e) Tangan jangan suka mengambil sesuatu yang bukan haknya

\section{TERJEMAHAN}

Dengan menyebut nama Allah yang maha pengasih lagi maha penyayang

Titip bayi ini wahai hutan dan kotoran

Ke daratan dan ke lautan Pagi dini hari dan tengah malam Siang bagaimanapun juga Titip kepada tuan nabi Muhammad 
Tabel 2

Unsur Isi Unsur Struktur

\section{Struktur}

$\begin{array}{lll}\text { Unsur Judul } & \text { Ngeureut santen } & \text { Ngeusian kanyut kunang } \\ \text { Unsur Pembuka } & \text { Bismilahirrahmaniirahim } & \text { Bismillahirrahmanirrahim } \\ \text { Unsur Sugesti } & - & \text { Pagi dini hari dan tengah malam } \\ \text { Unsur Tujuan } & & \text { Mihape ka kangjeng nabi } \\ & - & \text { Muhammad Incu putu nabi } \\ & & \text { adam }\end{array}$

4) Mantra ngalungkeun orok TRANSKRIPSI

\section{TERJEMAHAN}

Bismillahirrahmanirrahim

Dengan menyebut nama Allah yang maha pengasih lagi maha penyayang

Miceun budak

Membuang anak

nu ponok umurna

yang pendek umurnya

Anu belet anu euweuh milikan

Yang bodoh dan tidak ada

rezekinya

Mere orong-orong gogodongan

Ambillah wahai! orong-orong gogodongan (sejenis makhluk gaib yang jahat)

\section{5) Mantra mulung orok}

\section{TRANSKRIPSI}

Bismillahirrahmanirrahim

Eleh-eleh manggih budak Nu pinter

\section{TERJEMAHAN}

Dengan menyebut nama Allah yang maha pengasih lagi maha penyayang Eleh-eleh (sebuah ungkapan dalam bahasa Sunda) menemukan 
anak

Anu getol ngajina getol sakolana

Anu gede milik darajatna
Yang pintar

Yang rajin mengaji dan rajin

Sekolah

Yang besar rizki dan derajatnya

\section{Table 3}

\section{Unsur \\ Isi Unsur Struktur}

\section{Struktur}

Unsur Judul

Mulung Orok

Unsur Pembuka

Bismillahirrahmanirrahim

Unsur Sugesti

Eleh-eleh manggih budak

Unsur Tujuan

Yang pintar

Yang rajin mengaji dan rajin

sekolah

Yang besar rizki dan derajatnya
Ngalungkeun Orok

Bismillahirrahmanirrahim

Miceun budak

nu ponok umurna

Anu belet anu euweuh

milikan

Top mere orong-orong

gogodongan

\section{Makna Teks Mantra Mbeung Beurang}

Berdasarkan teks mantra-mantra di atas dapat disimpulkan bahwa maknamakna yang ada secara garis besarnya berisi tentang permohonan perlindungan kepada sang Penguasa dengan disertai pepatah-pepatah untuk kehidupan yang sesuai dengan asas hidup yang benar. Salah satu contohnya adalah pada mantra berikut: 
TRANSKRIPSI

Bismillahirrahmanirrahim

a) Ceupil ulah sakuping-kupingna lamun lain kupingeun nana

b) lambei ulah sok sacarioscariosna lamun lain cariosennana

c) soca ulah satingali-tingalieunna lamun lain tingalieunnana

d) sampean, ulah sok satincaktincakna lamun lain tincakeunnana

e) panangan ulah sok sacanakcanakna upami sanes canakeunana
TERJEMAHAN

Dengan menyebut nama Allah yang maha pengasih lagi maha penyayang

a) Telinga Jangan mendengarkan sesuatu yang tidak pantas didengar

b) Bibir jangan bicara sembarangan

c) Mata tidak boleh melihat sesuatu yang tidak pantas dilihat

d) Kaki jangan suka dilangkahkan untuk jalan yang tidak benar

e) Tangan jangan suka mengambil sesuatu yang bukan haknya

\section{Fungsi Teks Mantra Mbeung Beurang}

Mantra pada masyarakat di Desa Cidolog ini ada bermacam-macam fungsinya dalam memenuhi tujuan tertentu. Pada umumnya, fungsi mantra dapat dikatagorikan menjadi dua fungsi, yakni bersifat individual dan sosial. Fungsi yang bersifat individual dan yang bersifat sosial ini juga berlaku pada masyarakat di Desa Cidolog ini. Mantra bisa berfungsi dalam hubungannya dengan pengobatan, kecantikan, cinta kasih, kekebalan, dan keamanan.

Mantra yang dimaksud dalam fungsi individu ini hanya dirasakan atau dinikmati oleh orang-orang yang bersangkutan dalam rangka memenuhi kebutuhannya sendiri, sedangkan fungsi yang bersifat sosial tidak hanya digunakan untuk kepentingan dirinya sendiri, tetapi dapat juga dipergunakan untuk membantu orang lain, sehingga bermanfaat bagi masyarakat banyak. 
Kaitan dengan mantra-mantra yang didapatkan di Cidolog ini dapat dikategorikan sebagai mantra yang bersifat sosial, karena dari analisis yang telah dilakukan terhadap semua mantra yang didapati, mantra-mantra tersebut digunakan untuk kepentingan orang banyak, tidak untuk kepentingan individu semata. Hal yang paling utama dapat dikatakan bahwa mantra-mantra ini menjadikan semua masyarakat Cidolog pada masanya menjadi yakin akan kekuatan mantra sebagai pengganti kekuatan medis secara kekinian.

\section{PENUTUP}

Berdasarkan pembahasan di atas berikut beberapa temuan dalam analisis terhadap Teks Mantra Mbeung Beurang.

Pertama,struktur teks mantra Mbeung Beurang terdiri atas unsur-unsur pembangunnya, yaitu; unsur judul, unsur pembuka, unsur sugesti, dan unsur tujuan. Setiap unsur-unsurnya tersebut membuat sebuah keutuhan makna.

Kedua,teks mantra Mbeung Beurang sarat akan muatan nilai-nilai kehidupan. Makna yang terdapat dalam bentuk teks mantra ini adalah nilai-nilai kehidupan (pepatah bagaimana menggunakan semua anggota badan secara arif dan bijaksana). Dengan demikian, dari muatan makna yang terkandung dapat terlihat fungsi dari teksMbeung Beurang ini adalah fungsi pendidikan atau dapat dijadikan sebagai alat untuk menyebarkan pengetahuan (pendidikan). Masingmasing mantra selalu mengaitkan unsur-unsur ketaatan di dalamnya (setiap mantra selalu diawali dengan menyebut nama sang penguasa) hal tersebut menunjukkan sebuah sikap tunduk dan patuh kepada penguasa semesta. Mantra yang disampaikan Mbeung Beurangini apabila dicermati pada proses pertunjukkannya, maka jelas pesan yang berupa pepatah ini bisa diaplikasikan oleh orang-orang yang berada di sekitarnya, inti sebenarnya adalah pepatah untuk orang dewasa. 


\section{DAFTAR PUSTAKA}

Danandjaja, James. 2002. FolklorIndonesia: Ilmu Gosip, Dongeng, dan lain-lain. Jakarta: Grafiti.

Djamaris, Edwar, dkk. 1996. Nilai Budaya dalam Beberapa Karya Sastra Nusantara: Sastra Daerah di Kalimantan. Jakarta: Pusat Pembinaan dan Pengembangan Bahasa, Departemen Pendidikan dan Kebudayaan.Effendi,

Rustam. 2011. Sastra Banjar. Banjarbaru, Kalimantan Selatan: Scripta Cendekia.

Effendi, Rustam dan Sabhan. 2007. Sastra Daerah. PBS FKIP Universitas Lambung Mangkurat.

Heniati. 2010. Fungsi Mantra pada Masyarakat di Desa Jaweten Kecamatan Dusun Timur. Skripsi tidak diterbitkan. Banjarmasin FKIP UNLAM.

Ismail, Abdurachman, dkk. 1996. Fungsi Mantra dalam Masyarakat Banjar. Jakarta.

Soedjijono, dkk. 1987. Struktur dan Isi Mantra Bahasa Jawa di Jawa Timur. Jakarta: Departemen Pendidikan dan Kebudayaan.

Sudikan, Setya Yuwana. 2001. Metode Penelitian Kebudayaan. Surabaya: Unesa - Unipress dan Citra Wacana.

Sudjiman, Panuti. 1990. Kamus Istilah Sastra. Jakarta: UI Press. 